\title{
NEW ALGORITHM FOR ENERGY DISPATCH SCHEDULING OF GRID-CONNECTED SOLAR PHOTOVOLTAIC SYSTEM WITH BATTERY STORAGE SYSTEM
}

\begin{abstract}
Purpose. In last decade the problem of energy management system (EMS) for electric network has received special attention from academic researchers and electricity companies. In this paper, a new algorithm for EMS of a photovoltaic (PV) grid connected system, combined to an storage system is proposed for reducing the character of intermittence of PVs power which infect the stability of electric grid. In simulation model, the PV system and the energy storage system are connected to the same DC bus, whereas EMS controls the power flow from the PV generator to the grid based on the predetermined level of PV power. In the case where the $P V$ power is less than the predefined threshold, energy is stored in the batteries banc which will be employed in the peak energy demand (PED) times. Otherwise, it continues to feed the principal grid. The novelty of the proposed work lies in a new algorithm (smart algorithm) able to determine the most suitable (optimal) hours to switching between battery, Solar PVs, and principal grid based on historical consumption data and also determine the optimal amount of storage energy that be injected during the peak demand. Methods. The solution of the problem was implemented in the Matlab R2010a Platform and the simulation conducted on Laptop with a $2.5 \mathrm{GHz}$ processor and 4 GB RAM. Results. Simulation results show that the proposed model schedules the time ON/OFF of the switch in the most optimal way, resulting in absolute control of power electric path, i.e. precise adaptation at the peak without compromising consumers comfort. In addition, other useful results can be directly obtained from the developed scheme. Thus, the results confirm the superiority of the proposed strategy compared to other improved techniques. References 14, tables 1, figures 12.
\end{abstract}

Key words: PV generator and maximum power point tracker (MPPT), inverter, battery storage, management and control strategies, injection of energy.

\begin{abstract}
Мета. В останнє десятиліття проблемі системи енергоменеджменту (СЕМ) для електричної мережі приділялася особлива увага з боку науковиів та електроенергетичних компаній. У иій роботі пропонується новий алгоритм для СЕМ фотоелектричної (ФЕ) системи, підключеної до мережі, об'єднаної з системою накопичення енергї для зменшення характеру переривчастості потужності ФЕ системи, що впливає на стабільність електричної мережі. У розрахунковій моделі ФЕ система та система накопичення енергї підключені до однієї $і$ тієї ж шини постійного струму, тоді як СЕМ керує потоком потужності від ФЕ генератора до мережі на основі заздалегідь визначеного рівня потужності ФЕ. У тому випадку, коли потужність ФЕ менше заздалегідь визначеного порогу, енергія накопичується в батареях акумуляторів, що буде використано в часи пікового попиту на енергію. В іншому випадку ФЕ продовжуе живити основну мережу. Новизна запропонованої роботи полягає в новому алгоритмі (розумному алгоритмі), здатному визначити найбільш підходящі (оптимальні) години для перемикання між акумулятором, сонячними ФЕ та основною мережею на основі даних про історію споживання, а також визначити оптимальну величину енергіі накопичення, ще вводиться під час пікового попиту. Методи. Розв 'язання задачі було реалізовано на платформі Маtlab $R 2010 a$, а моделювання проведено на ноутбуиі з проиесором 2,5 ГГи та 4 ГБ оперативної пам'яті. Результати. Результати моделювання показують, щзо запропонована модель найоптимальніме планує час увімкнення/вимкнення вимикача, щзо призводить до абсолютного контролю потужності иляху електроенергії, тобто точної адаптації на піку без шкоди для комфорту споживачів. Крім того, з розробленої схеми можна безпосередньо отримати інші корисні результати. Таким чином, результати підтверджують перевагу запропонованої стратегії порівняно з іншими вдосконаленими методами. Бібл. 14, табл. 1, рис. 12.
\end{abstract}

Ключові слова: фотоелектричний генератор та трекер точки максимальної потужності, інвертор, акумулятор, стратегії управління та контролю, впорскування енергії.

Introduction. The photovoltaic (PV) technology has the reliability to become potentially one of the most important renewable energy sources for future electricity supply, Also under the implementing effective and efficient policies that attract sufficient investments to deploy renewable energy sources [1]. Also, the PV generators are environmentally friendly as that don't contribute air, water or greenhouse gas pollution [2].

The large-scale installation of photovoltaic distributed generators (PV-DG) connected on the low voltage grid; it requires more attention due to its impact on the electric grid. Because, high integration bring some negative impact on the system such as reverse power flow, voltage rise, transformer and cable rating, voltage unbalance and increase power losses [3].

A previous study also proved that the main factors for integrating renewable energy sources (RES) such as solar energy into the modern electricity grid are climate change [4], and due to the intermittent nature of solar energy, Therefore there is a difficulty in accurately predicting the power product by the PV-DG, then is injected to the grid.

A wide range of solution measures have been suggested in several literary works to reduce problems arising from by large scale PV integration into power grids [5]. In a paper [6], the author explains the accelerated energy transition using new datasets renewable energy data. Technological advancements in control and communication schemes lead to the modernity of the smart grid, and the role of the smart grid and the development of communication between devices and data analytics are very important in the effective and successful implementation of the proposed solutions.

It is recognized that the burden of voltage regulation falls in the PV producers, this requires the use of a smart grid that relies on Smart Meters to acquire and monitor the electrical signal characteristics signal during the day [7]. The suggested solutions to reduce voltage deviations problem is to constrain the PV generation during the

(C) F. Slama, H. Radjeai, S. Mouassa, A. Chouder 
lower energy demand. However, this solution it's not an appropriate ones, because leading to lost revenue to the producer resulting in limitation into increasing $\mathrm{PV}$ penetration. To avoid such solution, it is required of the PV producer using the storage system [8] in an effort to prevent leakage of this energy [9]. The authors in [10] present a study about a PV-battery energy storage system installed in a grid-connected residential house wherein daily experimental results shown that the presence of energy storage system has positive effect by reducing the peak energy demand (PED) in midday feed-in of excess PV power, thus providing benefits to the distribution network in terms of reduced peak load and voltage swings.

In view of aforementioned researches, we can see that almost of them rely on a permanent and accurate communication protocol and these clashes with the reality and capabilities of some rural families or poor countries as they using an unreliable communication network. This makes it difficult to implement the solution with the extreme precision suggested by previous authors. So an alternative solution was proposed in this paper, as the process of communication protocol for data entry has been facilitated, and it helps to expand the presence of photovoltaic energy within the energy system in rural areas and developing countries in particular.

This paper aims to present more discussions to create different models having ability to adapt with the conditions and possibilities available. The methodology consists of finding the optimal way to limit to feed the grid by the intermittent energy and to mitigate the impact of intermittence of PV power. In addition, the proposed algorithm is used to adjust the energy value which fed the grid by constant value within period's time despite constant changes in the atmosphere. For this purpose, the PV system and the energy storage system are connected to the same DC bus Fig. 1.

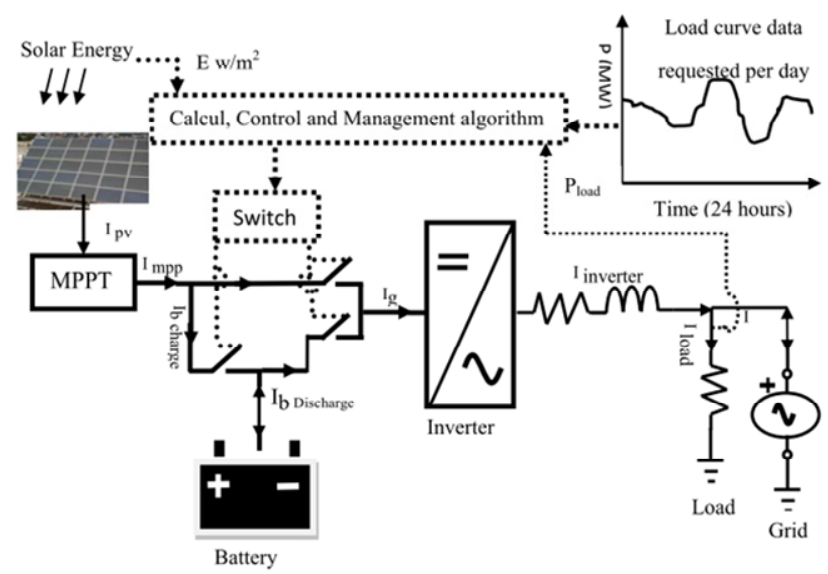

Fig. 1. Schematic of the system model illustrating the main components and energy

Among these positives, it also reduces the possible scenarios of grid-connected photovoltaic with storagebattery of home consumption as a fixed PV matrix size of $3 \mathrm{kWp}$. In the case where the PV power is less than the predefined threshold value, the energy is stored in the batteries bank, which will be used during PED hours. In the other case, it continues to feed the main grid. It is worth to mention that in this work, we are not interested in studying the capacity of battery storage; detailed study of battery storage are can be obtained in [11].

Modeling and simulation of the system and developed algorithm.

Photovoltaic module modeling system. Numerous models have been developed in the literature for describing the behavior of solar cells; a special attention has been focused on the single-diode model. Basically, the PV cell is a p-n junction semi-conductor which directly converts light energy into electricity. Its equivalent circuit is presented in Fig. 2 [12], in which indicated: $I_{p h}$ is the generated photo-current; $V_{D}$ is the voltage of diode VD; $R_{s h}$ is the shunt resistance which usually very large can be neglected; $R_{s}$ is the series resistance of the PV module; $I_{c e l}$ and $V_{c e l}$ are respectively current and voltage of cell.

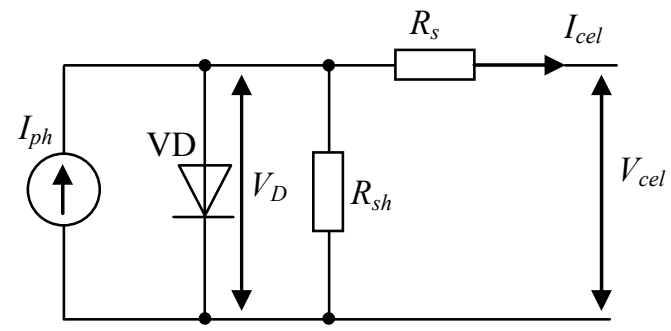

Fig. 2. Equivalent PV cell circuit

In order to extract maximum energy from the photoelectric cell shown in Fig. 2 and to get shape of the injected current into the grid, it's necessary to calculus the coordinates of the maximal power point $\left(V_{m p p}, I_{m p p}\right)$. Mathematically it can be defined by the following equations [13]:

$$
\begin{gathered}
I_{m p p}=N_{p} \cdot\left(I_{m r} \cdot \frac{E}{E_{n}}+K_{t}\left(T_{c}-T_{n}\right)\right) \\
V_{m p p}=N_{s} \cdot\left(V_{t} \cdot \ln \left(1+\frac{I_{s c}-I_{m p p}}{I_{s c}} \cdot\left(\exp \left(\frac{V_{o c}}{V_{t}}\right)-1\right)\right)-R_{s} I_{m p p}\right)
\end{gathered}
$$

where $N_{p}$ is the parallel cell number; $N_{s}$ is the series cell number; $I_{m r}$ is the reference short circuit current; $E$ is the irradiation $\left(\mathrm{W} / \mathrm{m}^{2}\right) ; E_{n}$ is the normalized insolation; $K_{t}$ is the temperature coefficient of cell short circuit current $I_{s c}$; $T_{c}$ is the cell temperature; $T_{n}$ is the normalized temperature; $R_{s}$ is the series resistance of the PV module; $V_{t}$ is the thermal voltage; $V_{o c}$ is the open-circuit voltage:

$$
\begin{gathered}
V_{t}=\frac{K \cdot B \cdot T_{c}}{q} ; \\
V_{o c}=\frac{B \cdot K}{q} \cdot \ln \left(\frac{I_{s c}}{I_{0}}+1\right) ; \\
I_{0}=I_{0 r} \cdot\left(\frac{T_{c}}{T_{n}}\right)^{3} \cdot \exp \left(\frac{q \cdot E_{g}}{B \cdot K} \cdot\left(\frac{1}{T_{n}}-\frac{1}{T_{c}}\right)\right),
\end{gathered}
$$

where $K$ is the Boltzmann's constant; $B$ is the diode quality factor; $q$ is the charge of an electron; $I_{0}$ is the saturation current of diode are given by [12]; $I_{0 r}$ is the reverse saturation current; $E_{g}$ - energy band gap.

To assess the behavior and simulation of the proposed system we have utilized the real data have been 
obtained from an acquisition system available in the Renewable Energy Development Center (REDC) in Algeria, as illustrated in the Fig. 3. The data used here are based on the real data of solar insulation and temperature of one day for both winter season and summer. In our application, module Isofoton $106 \mathrm{Wc}$ is used as PV generator. Table 1 summarizes the manufacturer characteristics of module, in which $V_{\max }$ is the maximum grid voltage; $\eta$ is the inverter efficiency; $L_{f}, R_{L f}$ are the inverter parameters.

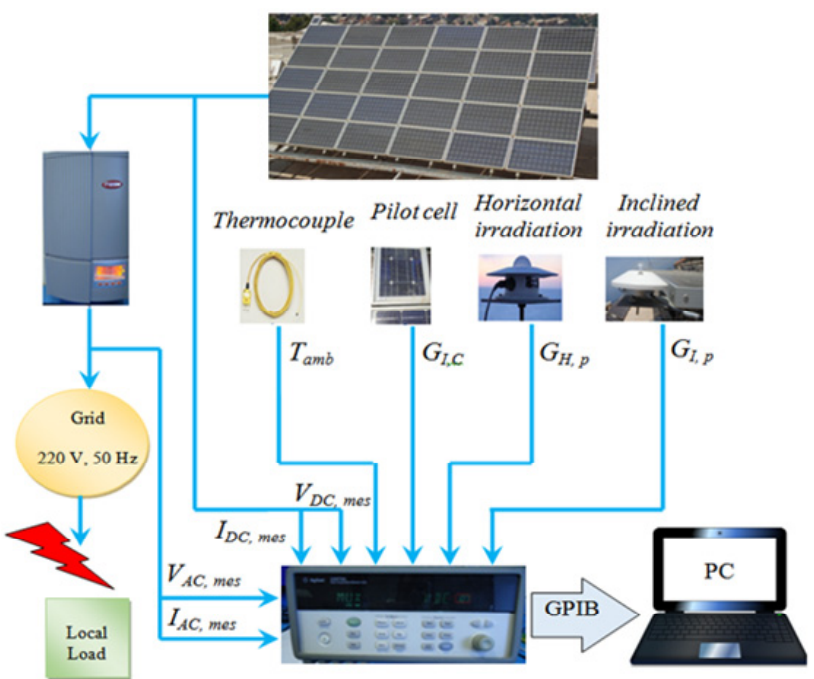

Fig. 3. Synoptic total of the system acquisition (GPIB - general purpose interface bus; $T_{a m b}$ - ambient temperature $\left({ }^{\circ} \mathrm{C}\right) ; G_{H, P}-$ global horizontal irradiation; $G_{I, C}$ and $G_{I, p}$ - inclined irradiation; $V_{D C \text {, mes }}-$ DC link voltage measured; $V_{A C \text {, mes }}-\mathrm{AC}$ voltage measured; $I_{D C \text {, mes }}-\mathrm{DC}$ link current measured; $I_{A C \text {,mes }}-\mathrm{AC}$ current measured)

Table 1

Simulation parameters values

\begin{tabular}{|c|c|c|c|}
\hline Parameters & Values & Parameters & Values \\
\hline$E_{n}$ & $1000 \mathrm{~W} / \mathrm{m}^{2}$ & $K_{t}$ & $2.3 \cdot 10^{-3} / 2 \mathrm{~A} /{ }^{\circ} \mathrm{C}$ \\
\hline$T_{n}$ & $298 \mathrm{~K}$ & $R_{s}$ & $0.153 \cdot 2 / 36 \Omega$ \\
\hline$I_{s c}$ & $6.69 / 2 \mathrm{~A}$ & $K$ & $1.38 .10^{-23} \mathrm{~J} / \mathrm{K}$ \\
\hline$V_{o c}$ & $20.32 / 36 \mathrm{~V}$ & $N_{s}$ & 540 \\
\hline$I_{0 r}$ & $1.406 \cdot 10^{-7} / 2 \mathrm{~A}$ & $N_{p}$ & 4 \\
\hline$I_{m r}$ & $6.03 / 2 \mathrm{~A}$ & $L_{f}$ & $0.02 \mathrm{H}$ \\
\hline$E_{g}$ & $1.12 \mathrm{eV}$ & $R_{L f}$ & $0.02 \Omega$ \\
\hline$q$ & $1.602 \cdot 10^{-19} \mathrm{C}$ & $V_{\max }$ & $220 \sqrt{2}$ \\
\hline$B$ & 1.3 & $\eta$ & 0.95 \\
\hline
\end{tabular}

Inverter modeling. The inverter connected to a grid receives the DC current from PV plant and converting it to $\mathrm{AC}$ current to inject in electric grid with unity power factor. A simplification has been introduced to the inverter model. The full bridge DC-AC converter is modeled as current controlled voltage source where the harmonic content is ignored. Fig. 4 shows the schematic diagram of grid connected inverter. The key variable for controlling this operation is the voltage of inverter $\left(V_{i n v}\right)$. The inverter current $\left(I_{g}\right)$ can be written as

$$
I_{g}=\frac{V_{i n v}-V_{a c}}{j L_{f} \omega},
$$

where $V_{i n v}$ is represent fundamental component of inverter output; $V_{a c}$ is the utility grid waveform; $\omega$ defines angular frequency of the voltage vector.

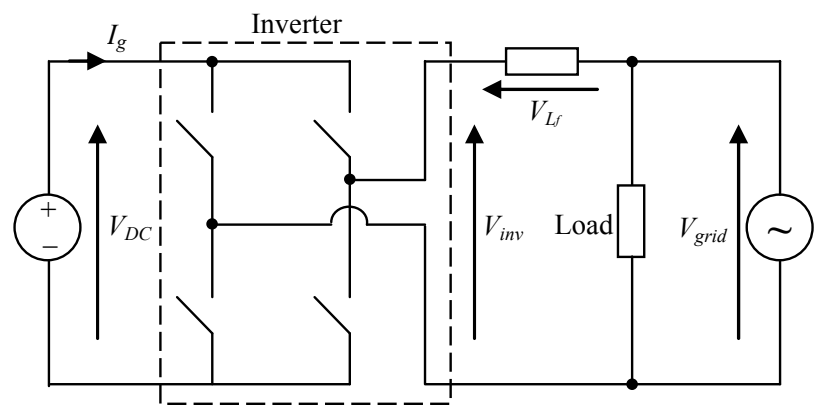

Fig. 4. Grid connected inverter

\section{Simulation of the PV grid inverter.}

The implementation of this system in MATLAB platform that the behaviour schematic of $\mathrm{PV}$ grid connected inverter is presented in Fig. 5. In this case indirect current control is used for drawing a reference $I_{g}$ current that must injected to the electric grid is calculated according the power produced from PV generator model and modelled as a controlled current source. The amplitude of current that inverter drawing in from continuous source is deduced by the power balancing principles [13].

$$
I_{g}=\frac{2 \cdot I_{m} \cdot V_{m} \cdot \eta}{V_{\max }}
$$

where $I_{m}$ and $V_{m}$ represent the coordinates of the maximal power point.

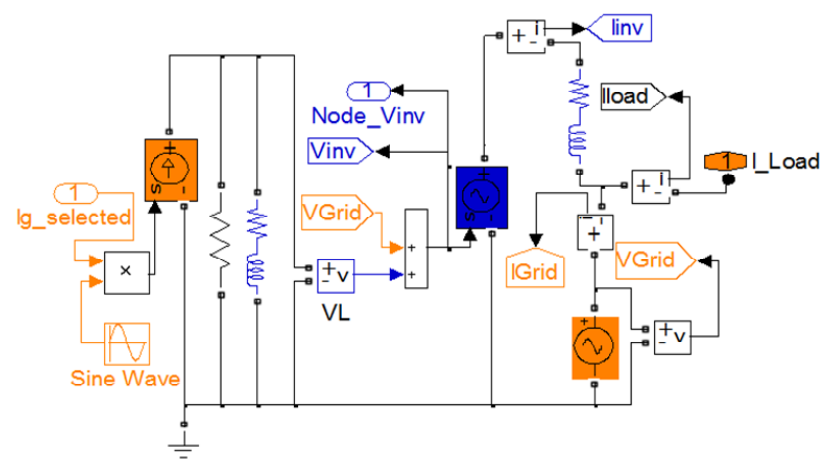

Fig. 5. Matlab schematic of PV grid connected inverter

Proposed algorithm. A major reason for grid data unavailability and transparency shortfall is data accessibility [14]. On the other hand, the input data needed by grid models or so-called grid data and their demands highly variant depending on the type of the grid model used. In this paper we focused only at the Load Curve Data required within day. Fig. 6, $a, b$ confirms that energy demand has nearly stable during of both monthly and seasonal periods. Thus, in order to fulfilling the gaps of data accessibility, the monthly load curve, which represents the inputs data of algorithm is obtained by using 30 daily load curves. The proposed algorithm can be summarized in a diagram as indicated in Fig. 7.

The work of the algorithm consists of several steps.

The first step to determine the time corresponding to the PED, within winter season there is only one peak of energy demand named $T_{\max 2}$, but at season summer, there 
is one off-peak hour between 2 on-peak hours demand, named, $T_{\min 3}, T_{\max 1}$ and $T_{\max 2}$ respectively. These peaks are calculated using algorithm shown in Fig. 8.

The second step is dedicated to find right time for charging the battery.

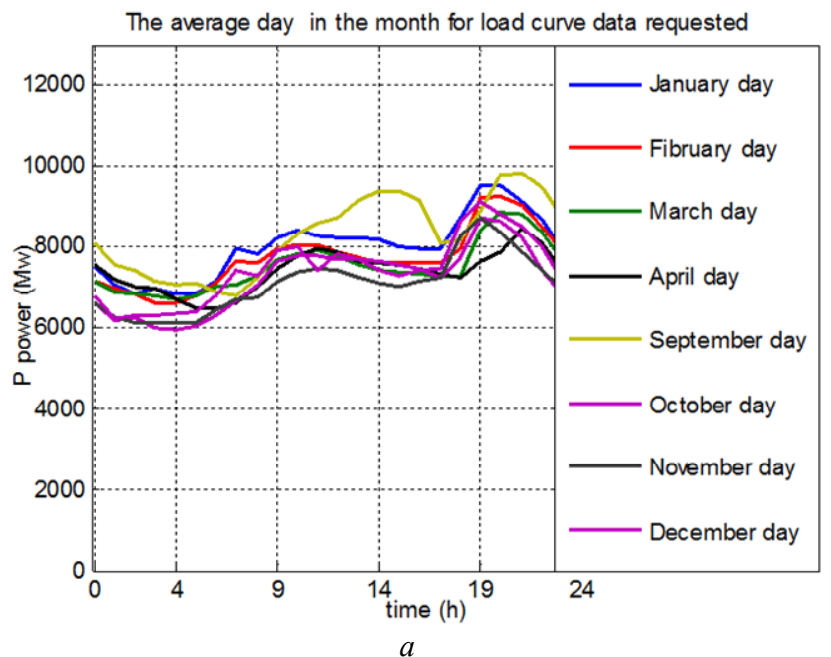

The third step consists to identify discharging time of battery according to the signal provided by the algorithm.

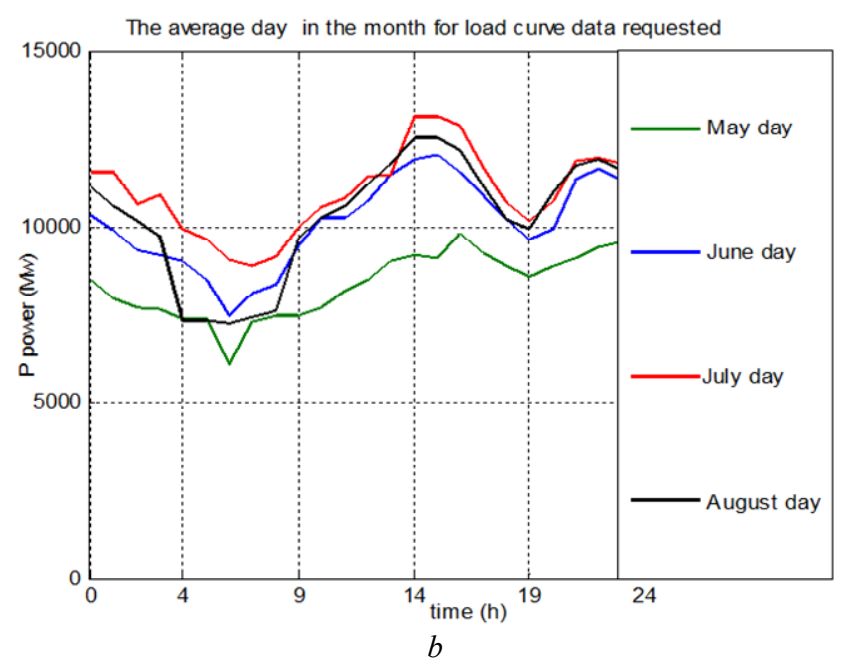

Fig. 6. Daily load curve data

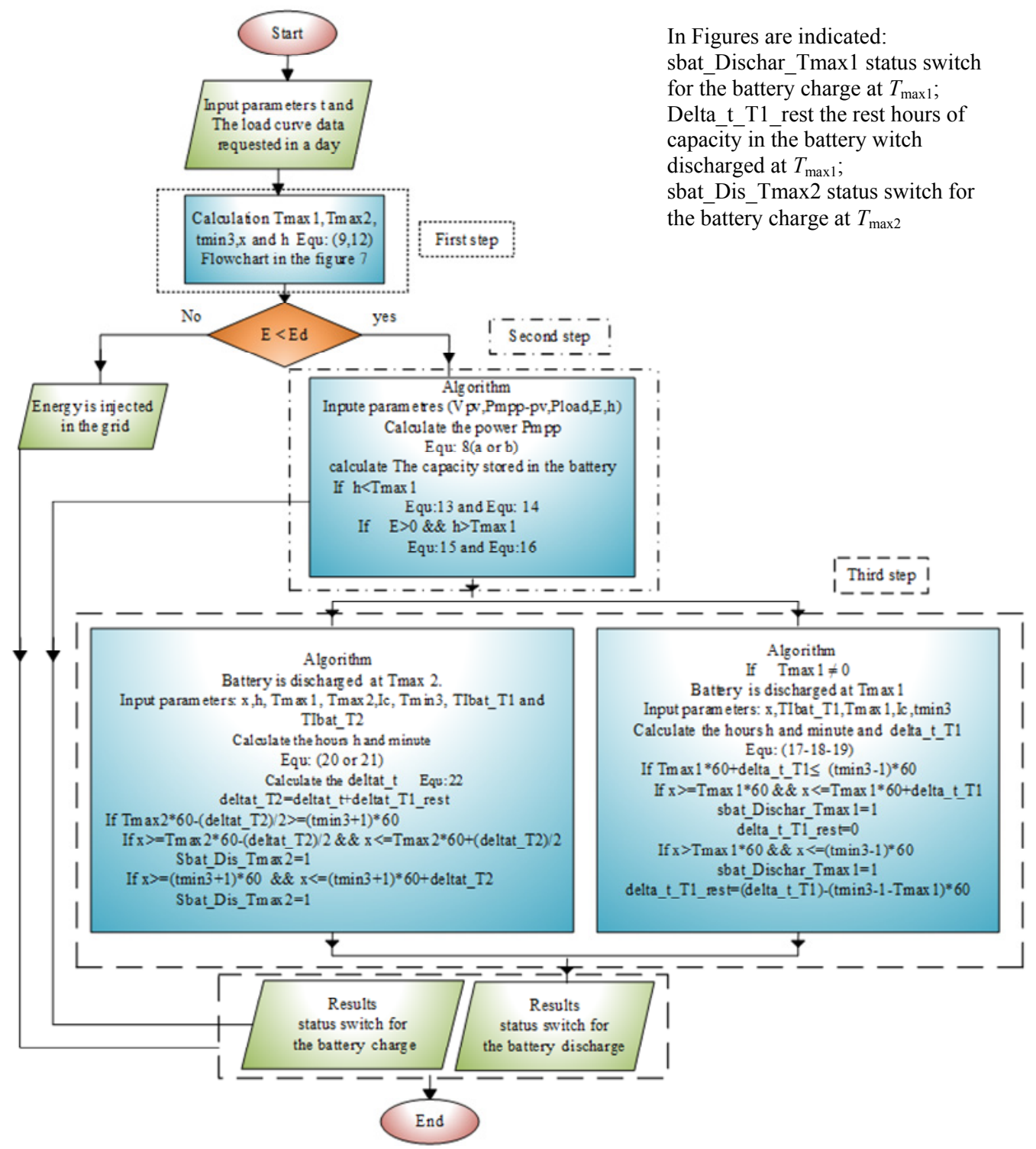

Fig. 7. Diagram of different stages of the algorithm 


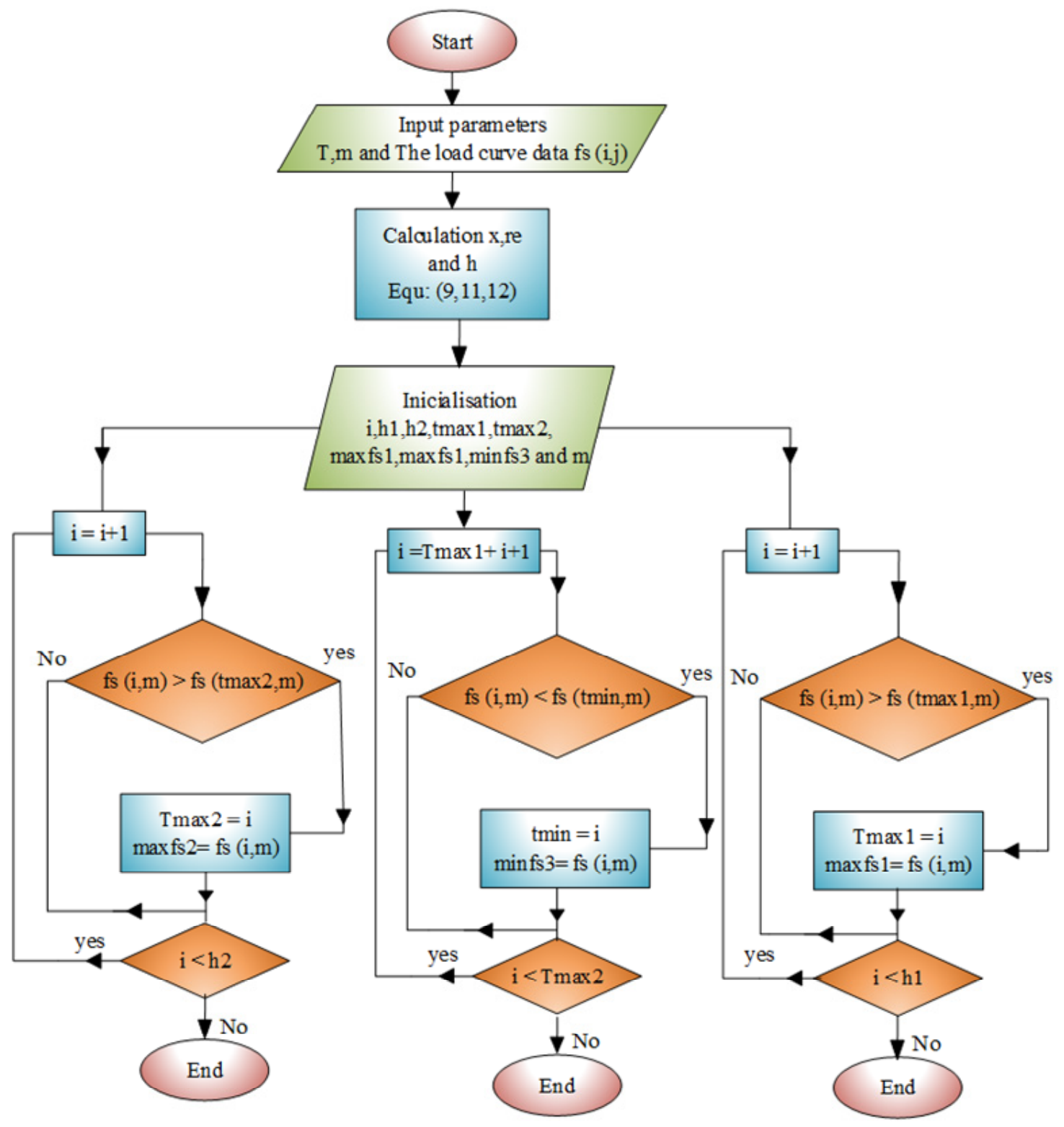

Fig. 8. Algorithm to define the time for $T_{\max 1}, T_{\max 2}$ and $T_{\min 3}$

Based on the data acquisition system using in Algerian Renewable Energy Development Center (AREDC) can extract a profile of solar radiation during a day, which contains $1440(24 \mathrm{~h} \times 60 \mathrm{~min})$ values of solar radiation, so that each minute in day represent a value of solar radiation as operation point. in other side, the simulation time required during 1440 operating points is $T_{S \max }$, in the same way we can determine simulation time in seconds that correspond of one value of solar radiation, (i.e., one operating point corresponding to a real single minute in day); thus, we can identify the real time in minutes $X$ and hours $h$ at any moment of simulation time. To this end, the proposed smart algorithm can easily managing the maximum and minimum peaks of energy, as well as staring time of charging and discharging batteries.

Follow calculate the power that will be stored in the batteries:

$$
\begin{array}{ll}
\Delta P=P_{m p p_{-} p v}-P_{\text {load }} & \text { if } \quad P_{m p p_{-} p v}>P_{\text {load }}(a) ; \\
\Delta P=P_{m p p_{-} p v} & \text { if } \quad P_{m p p_{-} p v}<P_{\text {load }}(b) ;
\end{array}
$$

$$
X=\varepsilon \cdot t,
$$

where $t$ is time of simulation; $P_{m p p_{-} p v}$ is the maximum power generated by the PV generator

$$
\begin{gathered}
\varepsilon=\frac{X_{\max }}{T_{S \max }} ; \\
r e=\operatorname{rem}(X, 60),
\end{gathered}
$$

where rem indicates of remainder after division; $T_{S \max }$ is the maximum simulation time; $X_{\max }$ is the maximum operating minutes.

$$
h=\frac{(X-r e)}{60} .
$$

Calculate the battery current $I_{\text {battery }} T_{1}$

$$
I_{\text {battery }_{-} T_{1}}=\frac{\Delta P}{V_{P V}} \text { if } h<T_{\max 1} .
$$

Calculate the total battery current before $T_{\max 1}$

$$
I_{\text {Ibat_ } T_{1}}=\text { coef } \times \sum I_{\text {battery_ } T_{1}}, \mathrm{~A} \cdot \mathrm{h} .
$$

Calculate the battery current $I_{\text {battery }} T_{2}$ 


$$
I_{\text {battery_ } T_{2}}=\frac{\Delta P}{V_{P V}} \text { if } h>T_{\max 1} .
$$

Calculate the total battery current after $T_{\max 1}$

$$
I_{{\text {Ibat_ } T_{2}}_{2}}=\text { coef } \cdot \sum I_{\text {battery }_{-} T_{2}}, \mathrm{~A} \cdot \mathrm{h} \text {. }
$$

Calculate the hours of capacity in the battery before $T_{\max 1}$ that will be discharged by the value of current $I_{c}$

$$
\begin{gathered}
\text { hours }=\text { floor }\left|\frac{T_{I b a t \_T 1}}{I_{c}}\right| ; \\
\text { minute }=\text { floor } \mid\left(\frac{T_{I b a t_{-} T 1}}{I_{c}}-\text { hours }\right) \cdot 60 \mid,
\end{gathered}
$$

where term floor () denotes the nearest integer less than or equal to hours or minutes.

Calculating $\Delta t T_{1}$ is the time of battery discharge

$$
\Delta t_{-} T_{1}=\text { hours } \cdot 60+\text { minute. }
$$

Calculate the hours of capacity in the battery after $T_{\max 1}$ that will be discharged by the value of current $I_{c}$

$$
\begin{aligned}
& \text { hours = floor }\left|\frac{T_{I b a t_{-} T_{2}}}{I_{c}}\right| \text { if } T_{\max 1} \neq 0 \\
& \text { minute }=\text { floor } \mid\left(\frac{T_{I b a t_{-} T_{2}}}{I_{c}}-\text { hour }\right) \cdot 60 \mid \text { if } T_{\max 1} \neq 0 \\
& \text { hours }=\text { floor }\left|\frac{T_{\text {Ibat_T1 }}+T_{\text {Ibat_T }}}{I_{c}}\right| \text { if } T_{\max 1}=0 \\
& \text { minute }=\text { floor } \mid\left(\frac{T_{\text {Ibat_T1 }}+T_{\text {Ibat_T }}}{I_{c}}-\text { hour }\right) \cdot 60 \mid \text { if } T_{\max 1}=0
\end{aligned}
$$

Calculating $\Delta t T_{2}$ is the time of battery discharge

$$
\Delta t_{-} \bar{T}_{2}=\text { hours } \cdot 60+\text { minute. }
$$

\section{Results and discussion.}

PED emerges as a phenomenon which epitomizes the relevance of social practices which lead us to our understanding of the dynamics of energy demand is the

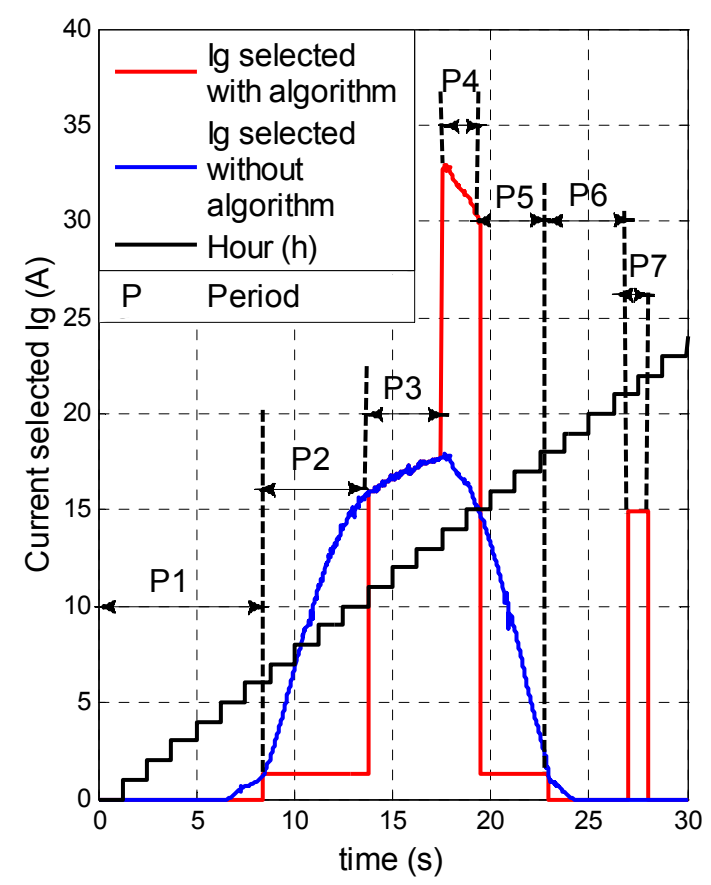

Fig. 9. Simulation shape of injected current $I_{g}$ position that the timing of energy demand is determined. It has been defined of PED times by using the smart algorithm, through the data base as shown in Fig. 4, which represents the energy demand curve for days for months of the year. For example, in January, we find that $T_{\max 2}=19 \mathrm{~h}, T_{\min 3}=16 \mathrm{~h}$, and in June we find that $T_{\max 1}=$ $14 \mathrm{~h}, T_{\max 2}=22 \mathrm{~h}$ and $T_{\min 3}=19 \mathrm{~h}$.

Simulation results for typical days, sunny and cloudy in the summer and winter, respectively. The value $I_{c}$ which represents the value of current when the battery is discharged is choosed in a proportional to the current $I_{p v}$ produced by the PV generator when the solar radiation $E$ is equal to the threshold $E_{d}$, in order to maintain the same size of electrical wires. As for the choice the threshold of solar radiation $E_{d}$, it is related to the storage capacity of the batteries, taking into account the cost, but in this study it was an experimental direct choice.

Simulation results by using the data of a day in the summer. Based on the daily load curve data for energy-consumption pattern illustrated in Fig. 6 and the weather conditions, we obtained the results presented in the Fig. 9 and Fig. 11, in which illustrates the different energy flow scenarios produced by the PV generator, over time periods determined and with different quantities, according to the solar radiation profile and the value of the energy stored in the batteries shown in Fig. 10 and Fig. 12.

Simulation results by using the data of a cloudy day in the winter. From Fig. 9 Period 1 it can be seen that before 06:52 AM, the value of the current $I_{g}$ is equal to 0 , which means that the photovoltaic generator (PVG) does not produce any energy due to the unavailability of sunlight; during this period the local load is totally supplied from public electric network, so $I_{g}=0$.

Period 2 within the interval time 06:52 am - 11:00 am, the PVG charges battery by current $I_{b}$, and supply the local load by energy, so $I_{g}=I_{p v}-I_{b}=I_{\text {load }}$.

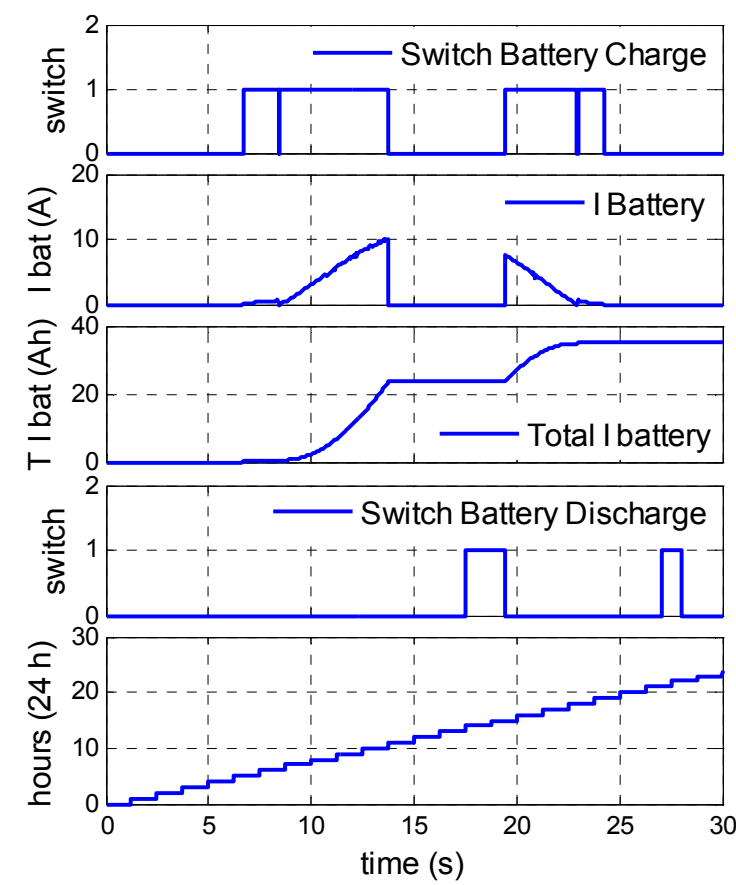

Fig. 10. Switch of control for simulation current of battery 


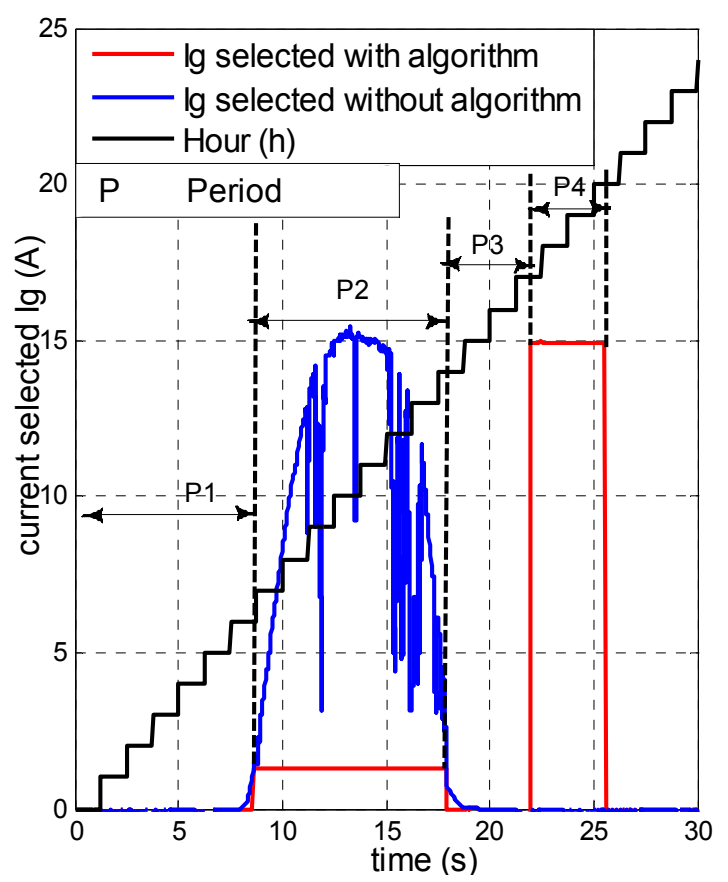

Fig. 11. Simulation shape of injected current $I_{g}$

Period 3 during 11:00 AM to 14:00 the local load is covered by PVG and the excess energy is injected into the network, because the solar radiation exceeds his threshold $E_{d}$. In addition, herein the battery is focused only to store intermittent energy causing from the weather conditions, or the solar radiation is inferior to his threshold, so $I_{g}=I_{p v}$.

Period 4 in the time domain of from 14:00 to $15: 47$, the PVG feeds the local load and contributes with battery to inject energy into the electrical network in coinciding with the time $T_{\max 1}$, the conjunction of PV systems with batteries enables as additional increase energy, so $I_{g}=I_{p v}+I_{b}$.

Period 5 within the interval time between 15:47 to $18: 21$, the PVG is charging a battery and the local load feed also, where $I_{g}=I_{p v}-I_{b}=I_{l o a d}$.

Period 6 the time interval between 18:21 to 21:13, the PVG doesn't generate electricity, due to the total absence of sunlight, so in this case the local charge is feed from the public network, so $I_{g}=I_{p v}=0$.

Period 7 in the last case, between $21: 13$ to $22: 47$, the battery are discharged into the public network in conjunction with $T_{\max 2}$ time, so the current $I_{g}=I_{b}$.

Figure 11 shows that over the course of the day, period 2 through 07:00 to 14:15 all the intermittent energy produced by the PVG is stored in the battery without resorting to feeding the grid with this fluctuating energy. In the end, this strategy was able to supply the main grid with energy during the peak, within a specified time interval period 4 between 17:30 to 20:20, which lead to facilitate the monitoring of the network's stability.

Conclusions.

In this paper, a new management scheme based on a system behavioral approach is proposed with a novel power flow management strategy to grid-connected PV system smart scheme, based on the real load curve data.

It is shown that the demand for energy is relatively stable within a month, which allowed us to understand the

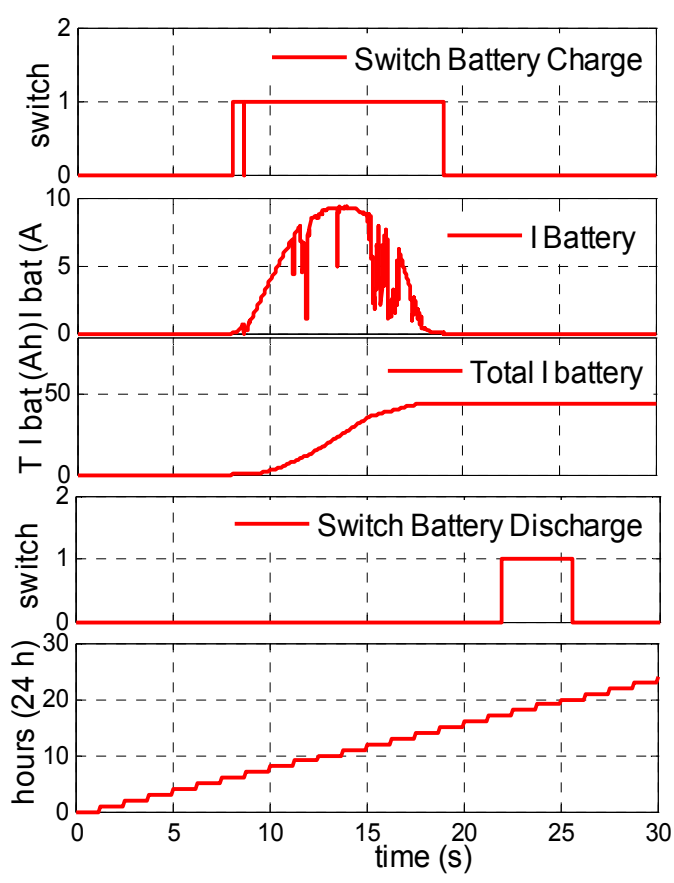

Fig. 12. Switch of control for simulation current of battery

dynamics of energy demand and we developed a novel strategy to facilitate the communication between the distributor of electricity dispatcher and the producer of energy generated by solar panels, so that the defect existing in this type of generator is corrected.

The proposed strategy describes how to exploit the power produced from PV generator based on determining the solar radiation threshold that is relied upon in specifying the energy path, either directly injected into the network or stored in order to inject later as per schedule given by algorithm.

This study not only allowed us to anticipate and estimate the amount of energy that will be injected into the network, but also to define the appropriate schedule for injection, supplying the network with energy at the peak energy demand times, in avoiding to supply intermittent power into network even under bad weather conditions. On the light of the obtained results, it would be very helpful and facile to control the stability dispatch in power networks. More importantly, the proposed strategy reduces the negativity of the intermittent nature of solar-energy, which encourages widespread investment in solar power generators.

\section{Acknowledgements.}

We gratefully acknowledge the support of the Renewable Energy Development Center (www.cder.dz) at Algeria. This work was supported fully by the University of Ferhat Abbas, Setif-1.

Conflict of interests. The authors declare no conflicts of interest.

\section{REFERENCES}

1. Polzin F., Egli F., Steffen B., Schmidt T.S. How do policies mobilize private finance for renewable energy? - A systematic review with an investor perspective. Applied Energy, 2019, vol. 236, pp. 1249-1268. doi: https://doi.org/10.1016/j.apenergy.2018.11.098.

2. Ivanova D., Barrett J., Wiedenhofer D., Macura B., Callaghan M., Creutzig F. Quantifying the potential for climate 
change mitigation of consumption options. Environmental Research Letters, 2020, vol. 15, no. 9, p. 093001. doi: https://doi.org/10.1088/1748-9326/ab8589.

3. Kenneth A.P., Folly K. Voltage rise issue with high penetration of grid connected PV. Conference Paper of 19th World Congress, International Federation of Automatic Control (IFAC, 2014), Cape Town, South Africa. August 24-29, 2014, vol. 19, no. 3. doi: $10.13140 / 2.1 .2274 .2406$.

4. Ascencio-Vásquez J., Brecl K., Topič M. Methodology of Köppen-Geiger-Photovoltaic climate classification and implications to worldwide mapping of PV system performance. Solar Energy, 2019, vol. 191, pp. 672-685. doi: https://doi.org/10.1016/j.solener.2019.08.072.

5. Sampath Kumar D., Gandhi O., Rodríguez-Gallegos C.D., Srinivasan D. Review of power system impacts at high PV penetration Part II: Potential solutions and the way forward. Solar Energy, 2020, vol. 210, pp. 202-221. doi: https://doi.org/10.1016/j.solener.2020.08.047.

6. Gielen D., Boshell F., Saygin D., Bazilian M.D., Wagner N., Gorini R. The role of renewable energy in the global energy transformation. Energy Strategy Reviews, 2019, vol. 24, pp. 3850. doi: https://doi.org/10.1016/i.esr.2019.01.006.

7. Benabdallah I., Oun A., Cherif A. Grid Connected PV Plant based on Smart Grid Control and Monitoring. International Journal of Advanced Computer Science and Applications, 2017, vol. 8, no. 6, pp. 299-306. doi: https://doi.org/10.14569/ijacsa.2017.080639.

8. Guidara I., Souissi A., Chaabene M. Novel configuration and optimum energy flow management of a grid-connected photovoltaic battery installation. Computers \& Electrical Engineering, 2020, vol. 85, p. 106677. doi https://doi.org/10.1016/j.compeleceng.2020.106677.

9. Ariyaratna P., Muttaqi K.M., Sutanto D. A novel control strategy to mitigate slow and fast fluctuations of the voltage profile at common coupling Point of rooftop solar PV unit with an integrated hybrid energy storage system. Journal of Energy Storage, 2018, vol. 20, pp. 409-417. doi: https://doi.org/10.1016/j.est.2018.10.016.

10. Bagalini V., Zhao B.Y., Wang R.Z., Desideri U. Solar PVBattery-Electric Grid-Based Energy System for Residential Applications: System Configuration and Viability. Research,
2019, vol. 2019, pp. 1-17. doi: https://doi.org/10.34133/2019/3838603.

11. Ru Y., Kleissl J., Martinez S. Exact sizing of battery capacity for photovoltaic systems. European Journal of Control, 2014, vol. 20, no. 1, pp. 24-37. doi: https://doi.org/10.1016/i.ejcon.2013.08.002.

12. Vinod, Kumar R., Singh S.K. Solar photovoltaic modeling and simulation: As a renewable energy solution. Energy Reports, 2018, vol. 4, pp. 701-712. doi: https://doi.org/10.1016/j.egyr.2018.09.008.

13. Slama F., Chouder A., Radjeai H. Simulation of Photovoltaic generator Connected To a Grid. Mediterranean Journal of Modeling and Simulation, 2014, no. 1, pp. 25-33.

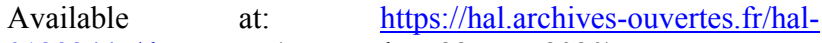
01293445/document (accessed on 22 June 2020).

14. Medjroubi W., Müller U.P., Scharf M., Matke C., Kleinhans D. Open Data in Power Grid Modelling: New Approaches Towards Transparent Grid Models. Energy Reports, 2017, vol. 3, pp. 14-21. doi: https://doi.org/10.1016/j.egyr.2016.12.001.

Received 01.11.2020

Accepted 14.12.2020

Published 25.02.2021

Fateh Slama ${ }^{1}$, Ph.D. Student,

Hamoud Radjeai ${ }^{1}$, Professor,

Souhil Mouassa ${ }^{2}$, Doctor of Engineering,

Aissa Chouder ${ }^{3}$, Professor,

${ }^{1}$ Department of Electrical Engineering,

Ferhat Abbas University of Setif 1, Algeria,

El Bez Campus, Setif 19000, Algeria,

e-mail: slama.fateh@univ-setif.dz, hradjeai@univ-setif.dz

${ }^{2}$ Department of Electrical Engineering,

University of Jaén,

23700 EPS Linares, Jaén, Spain

e-mail: souhil.mouassa@univ-bouira.dz

${ }^{3}$ Department of Electrical Engineering,

Mohamed Boudiaf University of M'Sila,

PB 166 M'sila 28000, Algeria,

e-mail: aissa.chouder@univ-msila.dz

How to cite this article:

Slama F., Radjeai H., Mouassa S., Chouder A. New algorithm for energy dispatch scheduling of grid-connected solar photovoltaic system with battery storage system. Electrical Engineering \& Electromechanics, 2021, no. 1, pp. 27-34. doi: 10.20998/2074272X.2021.1.05. 